\title{
Association of polymorphisms of SORBS1, GCK and WISP1 with hypertension in community-dwelling Japanese individuals
}

\begin{abstract}
Yoshiji Yamada $^{1}$, Fujiko Ando ${ }^{2,3}$ and Hiroshi Shimokata ${ }^{2}$
Although various loci and genes have been implicated in predisposition to hypertension by genetic linkage analyses and candidate gene association studies, the genes that confer susceptibility to this condition remain to be identified definitively. We have now examined the relationships of 22 candidate gene polymorphisms with the prevalence of hypertension and with blood pressure (BP) in a 6-year population-based longitudinal cohort study and observed significant relationships of three polymorphisms of SORBS1, GCK and WISP1 with hypertension. The 2233 subjects (1106 women, 1127 men) were aged 40-79 years and were randomly recruited to a population-based prospective cohort study of aging and age-related diseases in Japan. BP was measured with subjects having rested in the sitting position for at least 15 min. Genotypes for the $682 A \rightarrow G$ (Thr228Ala) polymorphism of SORBS1, the $-30 G \rightarrow$ A polymorphism of GCK and the $2364 A \rightarrow G$ polymorphism of WISP1 were determined by melting curve analysis. Longitudinal analysis with a generalized estimating equation revealed that the polymorphisms of SORBS1 and GCK and that of WISP1 were significantly associated with the prevalence of hypertension in women and men, respectively. Longitudinal analysis with a mixed-effect model revealed that the polymorphism of SORBS1 was significantly related to diastolic BP in women and that those of GCK and WISP1 were significantly related to both systolic and diastolic BP in women and men, respectively. These results suggest that SORBS1 and GCK are susceptibility loci for hypertension in Japanese women and that WISP1 is such a locus in men.
\end{abstract}

Hypertension Research (2009) 32, 325-331; doi:10.1038/hr.2009.23; published online 13 March 2009

Keywords: GCK; genetics; polymorphism; SORBS1; WISP1

\section{INTRODUCTION}

Hypertension is a complex multifactorial disorder that is thought to result from an interaction between an individual's genetic background and various environmental factors. ${ }^{1}$ Given that hypertension is a major risk factor for coronary heart disease, stroke and chronic kidney disease, personalized prevention of hypertension is an important public health goal. An approach to personalized prevention of, and selection of the most appropriate treatment for, hypertension is to identify genes that confer susceptibility to this condition. Although genetic linkage analyses, ${ }^{2-5}$ genome-wide mapping with microsatellite markers, ${ }^{6}$ genome-wide association studies $^{7}$ and candidate gene association studies $^{8-12}$ have implicated various loci and genes in predisposition to hypertension, the genes that confer susceptibility to this condition remain to be identified definitively. In addition, ethnic divergence of lifestyle and environmental factors as well as of genetic background necessitates examination of polymorphisms related to hypertension in each ethnic group.
With the use of a candidate gene approach, we have been attempting to identify genes associated with blood pressure (BP) and the prevalence of hypertension in Japanese women and men recruited to a population-based prospective cohort study. In this study, we have selected 22 candidate gene polymorphisms that might be expected to contribute to the regulation of BP and the development of hypertension (Table 1) and have examined the relationships of these polymorphisms with systolic and diastolic BP and the prevalence of hypertension, even though there is no apparent biological link among these genes. Our aim was to identify one to two genetic markers significantly associated with hypertension for each gene. Among the 22 polymorphisms examined in the study, the $682 \mathrm{~A} \rightarrow \mathrm{G}$ (Thr228Ala) polymorphism of SORBS1, the $-30 \mathrm{G} \rightarrow \mathrm{A}$ polymorphism of $G C K$ and the $2364 \mathrm{~A} \rightarrow \mathrm{G}$ polymorphism of WISP1 were significantly associated with hypertension in community-dwelling Japanese individuals. Given that among the various polymorphisms identified earlier, these polymorphisms were shown to be related to phenotypes, ${ }^{13-15}$ they might be expected to affect gene function. We now show the relationships of

${ }^{1}$ Department of Human Functional Genomics, Life Science Research Center, Mie University, Tsu, Mie, Japan; ${ }^{2}$ Department of Epidemiology, National Institute for Longevity Sciences, Obu, Aichi, Japan and ${ }^{3}$ Faculty of Medical Welfare, Department of Health Science, Aichi Shukutoku University, Nagoya, Aichi, Japan

Correspondence: Professor Y Yamada, Department of Human Functional Genomics, Life Science Research Center, Mie University, 1577 Kurima-machiya, Tsu, Mie 514-8507, Japan.

E-mail: yamada@gene.mie-u.ac.jp

Received 27 October 2008; revised 14 January 2009; accepted 19 January 2009; published online 13 March 2009 
Table 1 The 22 gene polymorphisms examined in this study

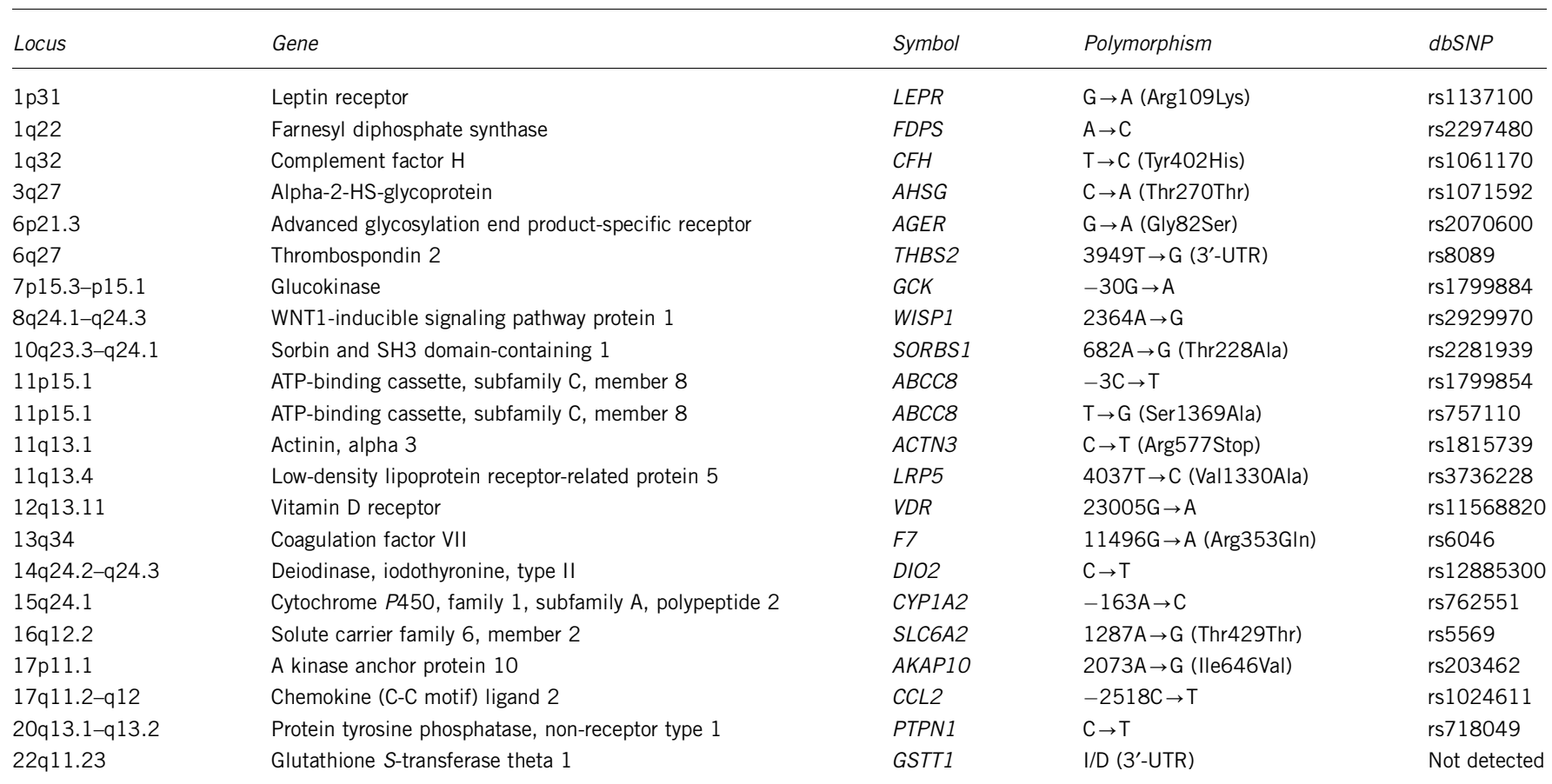

Table 2 Primers, probes and other PCR conditions for genotyping

\begin{tabular}{llllc}
\hline Gene & Polymorphism & Sense primer & Antisense primer & Probe with Texas red \\
\hline SORBS1 & 682A $\rightarrow$ G $($ Thr228Ala) & ATTTCATTCCCCCTCATCTGCAGAG & ACCAGCGGAGGTGGTGGTGAG & ATGGTGGCGCCTGGCTAAT \\
GCK & $-30 \mathrm{G} \rightarrow \mathrm{A}$ & CTCCTGGTCACCATGACAACCACAG & TGCTCCAGCCAGGTGTGGAGTG & CCTCTCAGGAGCACAGTAAGC \\
WISP1 & $2364 \mathrm{~A} \rightarrow \mathrm{G}$ & CAAATGGCCAGTTTTCTGGTAGGAAG & TTCAACCTCTTCAGCTTTAAACCTTTATTAAGTC & GGAGGTTACCGGTTGTTTAGA \\
\hline
\end{tabular}

Oligonucleotide sequences are $5^{\prime} \rightarrow 3^{\prime}$.

the polymorphisms of SORBS1, GCK and WISP1 with BP and the prevalence of hypertension in community-dwelling Japanese individuals.

\section{METHODS}

\section{Study population}

The National Institute for Longevity Sciences—-Longitudinal Study of Aging is a population-based prospective cohort study of aging and age-related diseases, the details of which have been described earlier. ${ }^{16-19}$ We examined the relationships of genetic variants with BP and the prevalence of hypertension in 2233 individuals (1106 women, 1127 men) recruited to the National Institute for Longevity Sciences-Longitudinal Study of Aging. Individuals whose genotypes were not successfully determined were excluded from the analysis. The study protocol complies with the Declaration of Helsinki and was approved by the Committee on Ethics of Human Research of the National Center for Geriatrics and Gerontology. Written informed consent was obtained from each subject.

\section{Measurement of BP}

Blood pressure was measured with an automatic sphygmomanometer (BP-203RV-II; Colin, Tokyo, Japan) in subjects who had rested in the sitting position for at least $15 \mathrm{~min}$. BP in each subject was confirmed by measurement with a mercury manometer performed by a physician according to the guidelines of the American Heart Association. ${ }^{20}$ Hypertension was defined as a systolic BP of $\geqslant 140 \mathrm{~mm} \mathrm{Hg}$, a diastolic BP of $\geqslant 90 \mathrm{~mm} \mathrm{Hg}$ or the taking of antihypertensive medication. Normal BP was defined as both a systolic BP of
$<140 \mathrm{~mm} \mathrm{Hg}$ and a diastolic BP of $<90 \mathrm{~mm} \mathrm{Hg}$ without the taking of antihypertensive medication.

\section{Genotyping of polymorphisms}

Genotypes for polymorphisms of SORBS1, GCK and WISP1 were determined by melting curve analysis (intercalater-mediated fluorescence resonance energy transfer probe method) (Table 2). The polymorphic region of each gene was amplified by PCR in a reaction mixture $(25 \mu \mathrm{l})$ containing $20 \mathrm{ng}$ of DNA, 5 pmol of each primer, $0.2 \mathrm{mmoll}^{-1}$ of each deoxynucleoside triphosphate, $2 \mathrm{mmoll}^{-1}$ (for SORBS1 and GCK) or $3 \mathrm{mmoll}^{-1}$ (for WISP1) $\mathrm{MgCl}_{2}$ and $1.25 \mathrm{U}$ of rTaq DNA polymerase (Toyobo, Osaka, Japan) in polymerase buffer. The amplification protocol comprised initial denaturation at $95^{\circ} \mathrm{C}$ for $5 \mathrm{~min} ; 45$ cycles of denaturation at $95^{\circ} \mathrm{C}$ for $30 \mathrm{~s}$, annealing at $65^{\circ} \mathrm{C}$ for $30 \mathrm{~s}$ and extension at $72^{\circ} \mathrm{C}$ for $30 \mathrm{~s}$; and a final extension at $72^{\circ} \mathrm{C}$ for $2 \mathrm{~min}$. A mixture $(2 \mu \mathrm{l})$ of 10 pmol of probe labeled at the $5^{\prime}$-end with Texas red and a 1:400 dilution of SYBR Green I was added to the PCR products, which was then transferred to a Prism 7700 instrument (Applied Biosystems, Foster City, CA, USA) for measurement of melting temperature. The program for analytical melting comprised incubation at $95^{\circ} \mathrm{C}$ for $30 \mathrm{~s}, 40^{\circ} \mathrm{C}$ for $1 \mathrm{~min}$ and temperatures increasing to $80^{\circ} \mathrm{C}$ over $10 \mathrm{~min}$. The fluorescence signals were detected at excitation and emission wavelengths of 485 and $612 \mathrm{~nm}$, respectively.

\section{Statistical analysis}

Age, body mass index, and systolic and diastolic BP were compared between subjects with hypertension and controls by the unpaired Student's $t$-test, and 
the prevalence of smoking was compared between the two groups by the $\chi^{2}$ test. $\mathrm{BP}$ values were analyzed in individuals who were not taking antihypertensive drugs. We examined the effects of genetic variants of SORBS1, GCK and WISP1 on the prevalence of hypertension and on systolic and diastolic BP based on a 6-year longitudinal cohort study. The data for examination of each subject in the first wave (November 1997 to April 2000), second wave (April 2000 to May 2002), third wave (May 2002 to May 2004) and fourth wave (June 2004 to July 2006) were pooled and analyzed. Systolic and diastolic BP and the prevalence of hypertension were evaluated for both sexes combined as well as for women and men separately. Longitudinal changes in the prevalence of hypertension were compared between two groups (dominant or recessive genetic model) by a generalized estimating equation, ${ }^{21}$ with adjustment for age and sex in all subjects or for age in women or men. Longitudinal changes in systolic and diastolic BP in individuals not taking antihypertensive medication were compared between two groups (dominant or recessive model) in a mixedeffect model, ${ }^{22}$ with adjustment for age and sex in all subjects or for age in women or men. Age-related changes in the prevalence of hypertension or in systolic or diastolic BP were estimated with quadratic curves controlling for the observation year during which the subjects attended at least one follow-up examination. Allele frequencies were estimated by the gene-counting method, and the $\chi^{2}$ test was used to identify significant departure from Hardy-Weinberg equilibrium. A $P$-value of $<0.05$ was considered statistically significant. Statistical analysis was performed with SAS software release 9.13 (SAS Institute, Cary, NC, USA).

\section{RESULTS}

The baseline characteristics (first wave) of the 2233 study subjects are shown in Table 3. Age, body mass index, as well as systolic and diastolic BP were greater in subjects with hypertension than in controls for both women and men, whereas the prevalence of smoking was greater in controls than in hypertensive subjects.

The relationships of the three polymorphisms with the prevalence of hypertension were analyzed with a generalized estimating equation and adjustment for age and sex in all subjects or for age in women or men examined separately (Table 4). The $682 \mathrm{~A} \rightarrow \mathrm{G}$ (Thr228Ala) polymorphism of SORBS1 and the $-30 \mathrm{G} \rightarrow \mathrm{A}$ polymorphism of $G C K$ were significantly associated with the prevalence of hypertension among women in a dominant model. The variant $G$ allele of the $S O R B S 1$ polymorphism was a risk factor for hypertension, whereas the variant $A$ allele of the GCK polymorphism was protective against this condition. The $2364 \mathrm{~A} \rightarrow \mathrm{G}$ polymorphism of WISP1 was significantly associated with the prevalence of hypertension among men in a dominant model, with the variant $G$ allele representing a risk factor for this condition. The genotype distributions of the three polymorphisms in control subjects were all in Hardy-Weinberg equilibrium. The relationships between the prevalence of hypertension and age analyzed longitudinally with a generalized estimating equation are shown in Figure 1. The prevalence of hypertension was greater in the combined group of all subjects with the $A G$ or GG genotype of SORBS1 than in those with the $A A$ genotype from 40 to 80 years of age (Figure 1a), was lower in the combined group of women with the $G A$ or $A A$ genotype of GCK than in those with the $G G$ genotype (Figure $1 b$ ) and was greater in the combined group of men with the $A G$ or $G G$ genotype of WISP1 than in those with the $A A$ genotype (Figure 1c).

The relationships of the three polymorphisms with systolic or diastolic BP in individuals not taking antihypertensive medication were analyzed with a mixed-effect model, with adjustment for age and sex in all subjects or for age in women or men examined separately (Table 5). The $682 \mathrm{~A} \rightarrow \mathrm{G}$ (Thr228Ala) polymorphism of SORBS1 was related to diastolic BP for women in a recessive model, with the variant $G$ allele being associated with increased $\mathrm{BP}$. The $-30 \mathrm{G} \rightarrow \mathrm{A}$ polymorphism of GCK was related to systolic and diastolic BP for women in a dominant model, with the variant $A$ allele being associated with a reduced BP. The $2364 \mathrm{~A} \rightarrow \mathrm{G}$ polymorphism of WISP1 was related to systolic and diastolic BP for men in a dominant model, with the variant $G$ allele being associated with a higher BP. The relationships between systolic or diastolic BP and age analyzed longitudinally according to genotype for WISP1 in men with a mixedeffect model are shown in Figure 2. Systolic (Figure 2a) and diastolic (Figure 2b) BPs were greater in the combined group of men with the $A G$ or $G G$ genotype of WISP1 than in those with the $A A$ genotype from 40 to 80 years of age.

\section{DISCUSSION}

The regulation of BP involves the integration of a variety of biological systems that control the structure and tone of the vasculature as well as the volume and composition of body fluid. It also involves the adaptation of these systems to constantly changing physiological needs. ${ }^{23}$ We have now examined the relationships of three candidate gene polymorphisms with the prevalence of hypertension and with systolic and diastolic BP in community-dwelling Japanese women and men. Our results show that the $682 \mathrm{~A} \rightarrow \mathrm{G}$ (Thr228Ala) polymorphism of SORBS1 and the $-30 \mathrm{G} \rightarrow \mathrm{A}$ polymorphism of $G C K$ were related to both the prevalence of hypertension and BP in women and that the $2364 \mathrm{~A} \rightarrow \mathrm{G}$ polymorphism of WISP1 was related to both these parameters in men. These observations thus suggest that SORBS1 and GCK are susceptibility loci for hypertension in Japanese women and that WISP1 is such a locus in men.

Table 3 Baseline characteristics (first wave) of women and men with hypertension and corresponding controls

\begin{tabular}{|c|c|c|c|c|c|c|}
\hline \multirow[b]{2}{*}{ Characteristic } & \multicolumn{3}{|c|}{ Women } & \multicolumn{3}{|c|}{ Men } \\
\hline & Hypertension & Control & P-value & Hypertension & Control & P-value \\
\hline Number of subjects $(n=2233)$ & 370 & 736 & & 356 & 771 & \\
\hline Age (years) & $64.4 \pm 0.5$ & $56.6 \pm 0.4$ & $<0.0001$ & $63.2 \pm 0.6$ & $57.3 \pm 0.4$ & $<0.0001$ \\
\hline Body mass index $\left(\mathrm{kg} \mathrm{m}^{-2}\right)$ & $24.0 \pm 0.2$ & $22.4 \pm 0.1$ & $<0.0001$ & $23.7 \pm 0.1$ & $22.6 \pm 0.1$ & $<0.0001$ \\
\hline Smoking $(n(\%))$ & $18(4.9)$ & $61(8.3)$ & 0.0375 & $99(27.8)$ & $330(42.8)$ & $<0.0001$ \\
\hline Systolic BP (mm Hg) & $143.1 \pm 0.8$ & $113.6 \pm 0.5$ & $<0.0001$ & $141.0 \pm 0.8$ & $115.9 \pm 0.5$ & $<0.0001$ \\
\hline Diastolic BP (mm Hg) & $84.0 \pm 0.5$ & $69.5 \pm 0.3$ & $<0.0001$ & $85.9 \pm 0.5$ & $72.3 \pm 0.3$ & $<0.0001$ \\
\hline Number of subjects $(n=1781)^{a}$ & 144 & 736 & & 130 & 771 & \\
\hline Systolic BP (mm Hg) & $150.4 \pm 1.0$ & $113.6 \pm 0.5$ & $<0.0001$ & $150.3 \pm 1.1$ & $115.9 \pm 0.4$ & $<0.0001$ \\
\hline Diastolic BP (mm Hg) & $88.1 \pm 0.7$ & $69.5 \pm 0.3$ & $<0.0001$ & $92.5 \pm 0.7$ & $72.3 \pm 0.3$ & $<0.0001$ \\
\hline
\end{tabular}

Data for age, body mass index and blood pressure (BP) are means \pm s.e.

asubjects not taking antihypertensive medication. 
Table 4 Relations of three polymorphisms to the prevalence of hypertension analyzed with a generalized estimating equation (first wave to fourth wave)

\begin{tabular}{|c|c|c|c|c|c|c|c|}
\hline Gene symbol & Polymorphism & Subjects & Genotype & Hypertension & Control & P-value (dominant) & P-value (recessive) \\
\hline \multirow[t]{7}{*}{ SORBS1 } & $682 \mathrm{~A} \rightarrow \mathrm{G}($ Thr228Ala) & & & & & & \\
\hline & & Total & $A A$ & $1792(76.5)$ & $3818(80.1)$ & 0.0039 & 0.1749 \\
\hline & & & $G G$ & $39(1.7)$ & $55(1.2)$ & & \\
\hline & & Women & $A A$ & $847(77.0)$ & $1891(80.6)$ & 0.0249 & 0.3641 \\
\hline & & & $A G$ & $227(20.6)$ & 417 (17.8) & & \\
\hline & & & $A G$ & 285 (22.9) & 479 (19.8) & & \\
\hline & & & $G G$ & $13(1.1)$ & $16(0.7)$ & & \\
\hline \multirow[t]{6}{*}{ GCK } & $-30 G \rightarrow A$ & & & & & & \\
\hline & & Total & $G G$ & 1639 (69.7) & 3006 (62.9) & 0.0068 & 0.5414 \\
\hline & & & $G A$ & $638(27.1)$ & $1597(33.4)$ & & \\
\hline & & Men & $G G$ & $841(67.4)$ & $1543(63.7)$ & 0.3861 & 0.7655 \\
\hline & & & $G A$ & $359(28.8)$ & 799 (33.0) & & \\
\hline & & & $A A$ & $47(3.8)$ & $80(3.3)$ & & \\
\hline \multirow[t]{7}{*}{ WISP1 } & $2364 \mathrm{~A} \rightarrow \mathrm{G}$ & & & & & & \\
\hline & & Total & $A A$ & $895(38.2)$ & $1919(40.2)$ & 0.0184 & 0.4578 \\
\hline & & & $A G$ & $1133(48.3)$ & $2219(46.5)$ & & \\
\hline & & & $G G$ & 318 (13.6) & 635 (13.3) & & \\
\hline & & Women & $A A$ & $458(41.7)$ & 929 (39.5) & 0.5437 & 0.2908 \\
\hline & & & $A G$ & $526(47.9)$ & $1108(47.1)$ & & \\
\hline & & & $G G$ & $115(10.5)$ & $315(13.4)$ & & \\
\hline
\end{tabular}

The prevalence of hypertension was compared between two groups (dominant or recessive model) for each polymorphism, with adjustment for age and sex in all subjects or for age in women or men examined separately.

Values in parentheses are percentages. $P$-values of $<0.05$ are shown in bold.
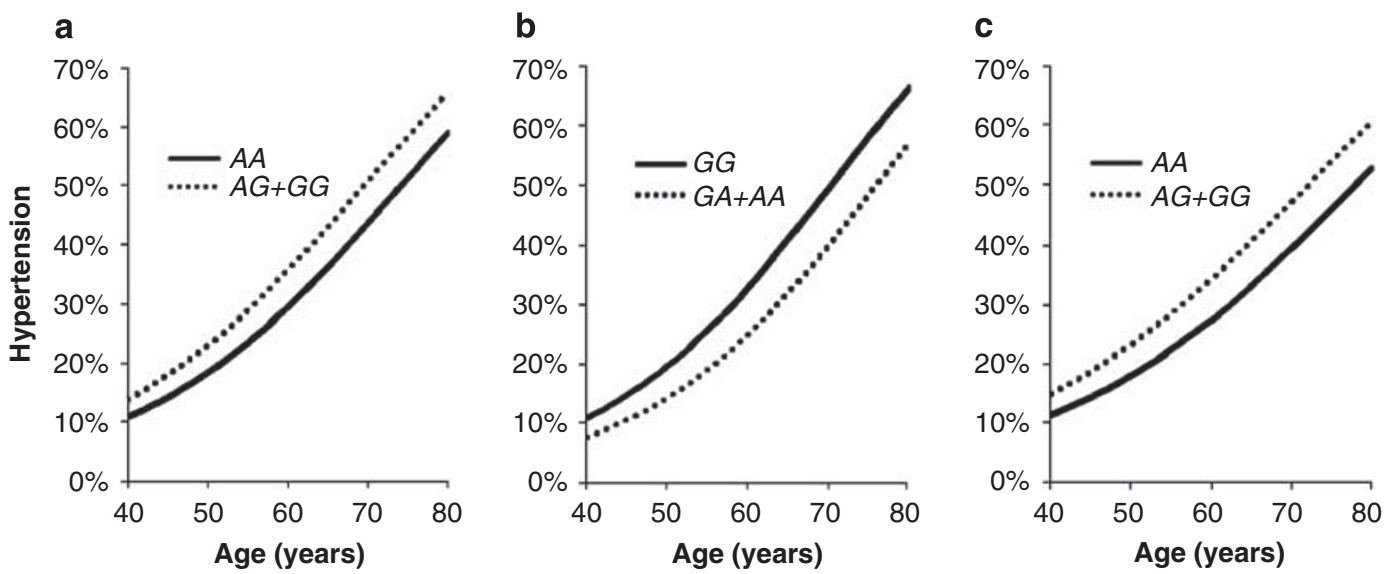

Figure 1 Longitudinal analysis of relationships between the prevalence of hypertension and age according to genotype for SORBS1 (AA vs. AG+GG) in women and men combined (a), for GCK (GG vs. GA+AA) in women (b) or for WISP1 ( $A A$ vs. $A G+G G$ ) in men (c), with a generalized estimating equation and adjustment for either age and sex (a) or age (b and $\mathbf{c})$.

Sorbin and SH3 domain-containing 1 (SORBS1) is a human homolog of c-Cbl-associated protein (CAP), ${ }^{24}$ which is an important signaling molecule in insulin stimulation of glucose uptake in mouse adipocytes. ${ }^{24-27}$ Phosphorylation of c-Cbl results in the dissociation of the c-Cbl-CAP complex from the insulin receptor and its translocation to a lipid raft domain of the plasma membrane. Subsequent 
Table 5 Relations of three polymorphisms to systolic and diastolic blood pressure (BP, $\mathrm{mm} \mathrm{Hg}$ ) in individuals not taking antihypertensive medication as analyzed with a mixed-effect model (first wave to fourth wave)

\begin{tabular}{|c|c|c|c|c|c|c|c|c|c|}
\hline \multirow{2}{*}{$\begin{array}{l}\text { Gene symbol } \\
\text { SORBS1 }\end{array}$} & \multirow{2}{*}{$\begin{array}{l}\text { Polymorphism } \\
682 \mathrm{~A} \rightarrow \mathrm{G} \text { (Thr228Ala) }\end{array}$} & & & \multicolumn{2}{|c|}{ Dominant model } & \multirow[t]{2}{*}{$\mathrm{P}$-value } & \multicolumn{2}{|c|}{ Recessive model } & \multirow[t]{2}{*}{$P$} \\
\hline & & & & $A A$ & $A G+G G$ & & $A A+A G$ & $G G$ & \\
\hline & & Total & Sample no. & 4407 & 1093 & & 5432 & 68 & \\
\hline & & & Systolic BP & $119.9 \pm 0.4$ & $120.3 \pm 0.8$ & 0.6179 & $119.9 \pm 0.4$ & $123.7 \pm 3.1$ & 0.2355 \\
\hline & & & Diastolic BP & $73.8 \pm 0.2$ & $73.9 \pm 0.5$ & 0.8963 & $73.8 \pm 0.2$ & $76.6 \pm 1.9$ & 0.1379 \\
\hline & & Women & Sample no. & 2157 & 520 & & 2627 & 50 & \\
\hline & & & Systolic BP & $118.6 \pm 0.6$ & $118.7 \pm 1.2$ & 0.8973 & $118.5 \pm 0.5$ & $124.7 \pm 3.7$ & 0.0939 \\
\hline & & & Diastolic BP & $72.2 \pm 0.4$ & $72.1 \pm 0.7$ & 0.8528 & $72.1 \pm 0.3$ & $76.4 \pm 2.2$ & 0.0471 \\
\hline & & Men & Sample no. & 2250 & 573 & & 2805 & 18 & \\
\hline & & & Systolic BP & $121.1 \pm 0.6$ & $121.7 \pm 1.1$ & 0.6246 & $121.3 \pm 0.5$ & $117.1 \pm 6.2$ & 0.5007 \\
\hline & & & Diastolic BP & $75.4 \pm 0.3$ & $75.6 \pm 0.7$ & 0.7841 & $75.5 \pm 0.3$ & $73.3 \pm 3.7$ & 0.5700 \\
\hline \multirow[t]{10}{*}{ GCK } & $-30 G \rightarrow A$ & & & $G G$ & $G A+A A$ & & $G G+G A$ & $A A$ & \\
\hline & & Total & Sample no. & 3490 & 2020 & & 5310 & 200 & \\
\hline & & & Systolic BP & $120.3 \pm 0.5$ & $119.4 \pm 0.6$ & 0.2339 & $120.0 \pm 0.4$ & $120.4 \pm 1.9$ & 0.8164 \\
\hline & & & Diastolic BP & $74.1 \pm 0.3$ & $73.4 \pm 0.4$ & 0.1399 & $73.8 \pm 0.2$ & $74.5 \pm 1.1$ & 0.5721 \\
\hline & & Women & Sample no. & 1683 & 1004 & & 2580 & 107 & \\
\hline & & & Systolic BP & $119.5 \pm 0.7$ & $117.1 \pm 0.9$ & 0.0262 & $118.6 \pm 0.5$ & $118.9 \pm 2.7$ & 0.9182 \\
\hline & & & Diastolic BP & $72.8 \pm 0.4$ & $71.2 \pm 0.5$ & 0.0120 & $72.2 \pm 0.3$ & $72.7 \pm 1.6$ & 0.7506 \\
\hline & & Men & Sample no. & 1807 & 1016 & & 2730 & 93 & \\
\hline & & & Systolic BP & $121.0 \pm 0.6$ & $121.7 \pm 0.8$ & 0.5117 & $121.2 \pm 0.5$ & $122.0 \pm 2.6$ & 0.7819 \\
\hline & & & Diastolic BP & $75.3 \pm 0.4$ & $75.7 \pm 0.5$ & 0.6084 & $75.4 \pm 0.3$ & $76.3 \pm 1.6$ & 0.5897 \\
\hline \multirow[t]{10}{*}{ WISP1 } & $2364 \mathrm{~A} \rightarrow \mathrm{G}$ & & & $A A$ & $A G+G G$ & & $A A+A G$ & $G G$ & \\
\hline & & Total & Sample no. & 2195 & 3309 & & 4766 & 738 & \\
\hline & & & Systolic BP & $119.1 \pm 0.6$ & $120.5 \pm 0.5$ & 0.0573 & $119.9 \pm 0.4$ & $120.5 \pm 1.0$ & 0.5698 \\
\hline & & & Diastolic BP & $73.3 \pm 0.3$ & $74.2 \pm 0.3$ & 0.0522 & $73.8 \pm 0.2$ & $74.4 \pm 0.6$ & 0.3371 \\
\hline & & Women & Sample no. & 1074 & 1608 & & 2330 & 352 & \\
\hline & & & Systolic BP & $118.6 \pm 0.8$ & $118.6 \pm 0.7$ & 0.9498 & $118.6 \pm 0.6$ & $118.9 \pm 1.5$ & 0.8248 \\
\hline & & & Diastolic BP & $72.2 \pm 0.5$ & $72.2 \pm 0.4$ & 0.9953 & $72.2 \pm 0.3$ & $72.4 \pm 0.9$ & 0.8283 \\
\hline & & Men & Sample no. & 1121 & 1701 & & 2436 & 386 & \\
\hline & & & Systolic BP & $119.6 \pm 0.8$ & $122.3 \pm 0.6$ & 0.0073 & $121.2 \pm 0.5$ & $121.9 \pm 1.3$ & 0.6141 \\
\hline & & & Diastolic BP & $74.4 \pm 0.5$ & $76.1 \pm 0.4$ & 0.0057 & $75.3 \pm 0.3$ & $76.2 \pm 0.8$ & 0.2939 \\
\hline
\end{tabular}

Systolic or diastolic BP was compared between two groups (dominant or recessive model) for each polymorphism, with adjustment for age and sex in all subjects or for age in women or men examined separately.

$P$-values of $<0.05$ are shown in bold.
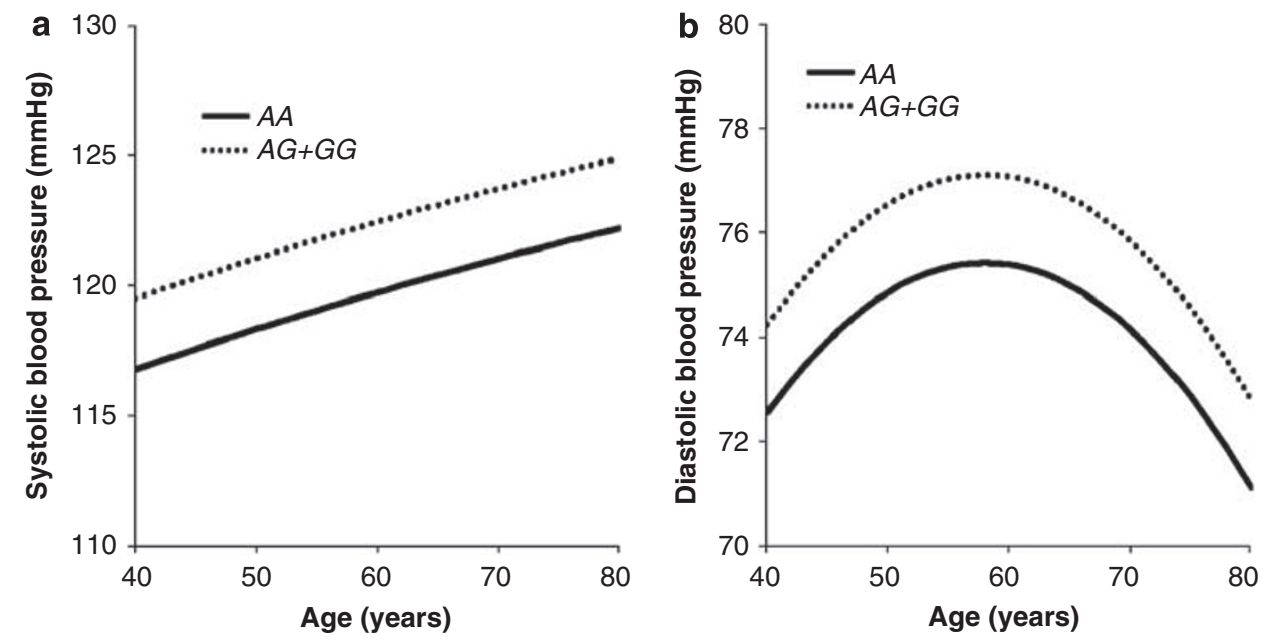

Figure 2 Longitudinal analysis of relationships between systolic (a) or diastolic (b) BP and age according to genotype for WISP1 (AA vs. AG+GG) in men with a mixed-effect model and adjustment for age.

interactions of the c-Cbl-CAP complex with proteins such as flotillin, Crk $\alpha$, C3G and TC10 eventually leads to the translocation of vesicles containing the glucose transporter SLC2A4 (GLUT4) from the cyto- plasm to the plasma membrane. The central role of the c-Cbl-CAP complex in the regulation of insulin-stimulated glucose uptake suggests that genetic variation of SORBS1 may be related to insulin 
resistance. Fourteen single-nucleotide polymorphisms have been identified in human SORBS1, among which, only $682 \mathrm{~A} \rightarrow \mathrm{G}$ (Thr228Ala), which corresponds to a predicted phosphorylation site for mitogenactivated protein kinase, was found to be related to obesity and type 2 diabetes mellitus in Chinese adults, with the $G$ allele being protective against these conditions. ${ }^{13}$ In contrast, the $G G$ (Ala/Ala) genotype of the $682 \mathrm{~A} \rightarrow \mathrm{G}$ (Thr228Ala) polymorphism of SORBS1 was associated with lacunar infarction in the Japanese population. ${ }^{28}$ The $682 \mathrm{~A} \rightarrow \mathrm{G}$ (Thr228Ala) polymorphism (rs2281939) is located in exon 7 of SORBS1. A linkage disequilibrium (LD) block (standardized LD coefficient $\left(r^{2}\right) \geqslant 0.3$ ) containing this polymorphism includes $\sim 5 \mathrm{~kb}$ from exon 7 to the $3^{\prime}$ region of the gene (International HapMap Project, http://www.hapmap.org/index.html.ja). We have now shown that this polymorphism of SORBS1 was related to both the prevalence of hypertension and diastolic BP in Japanese women, with the $G$ (Ala) allele representing a risk factor for hypertension. The risk allele for hypertension is thus consistent with that for lacunar infarction in the earlier study. ${ }^{28}$

Glucokinase is expressed in pancreatic $\beta$ cells and hepatocytes, with its expression being controlled by two tissue-specific gene promoters. ${ }^{29}$ Pancreatic glucokinase serves as the sensor for glucose in the regulation of insulin secretion. ${ }^{30}$ Mutations of GCK account for $10-50 \%$ of cases of maturity-onset diabetes of the young. ${ }^{30}$ The $-30 \mathrm{G} \rightarrow$ A polymorphism of GCK was shown to be associated with reduced $\beta$-cell function and impaired glucose tolerance in Japanese population. ${ }^{14,31}$ The $-30 \mathrm{G} \rightarrow$ A polymorphism (rs1799884) is located in the $\beta$-cell-specific promoter region of GCK. An LD block containing this polymorphism includes $\sim 7.5 \mathrm{~kb}$ from $5^{\prime}$ region of the gene to intron 2. The $A$ allele of this polymorphism was also found to increase the risk for coronary heart disease and was consistently related to this condition after adjustment for type 2 diabetes mellitus in a white population. ${ }^{32}$ The risk for coronary heart disease conferred by the $A$ allele was even greater in individuals with type 2 diabetes mellitus than in non-diabetic individuals. We have shown earlier that the $-30 \mathrm{G} \rightarrow \mathrm{A}$ polymorphism of $G C K$ was associated with hypertension, with the $A$ allele being protective against this condition, in a crosssectional case-control study. ${ }^{11}$ We have now shown that this polymorphism was related to both the prevalence of hypertension and systolic and diastolic BP in Japanese women, with the variant $A$ allele protecting against hypertension, consistent with our earlier study. ${ }^{11}$ The mechanisms responsible for the association of the $A$ variant with an increased risk of coronary heart disease, ${ }^{32}$ with reduced $\beta$-cell function and impaired glucose tolerance, ${ }^{14,31}$ and with a reduced risk of hypertension (present study) remain to be elucidated. The $-258 \mathrm{G} \rightarrow$ A polymorphism located in the liver-specific promoter of GCK was also shown to be associated with hypertension in a Taiwanese population. ${ }^{33}$

Wingless-type MMTV (mouse mammary tumor virus) integration site family member 1 (WNT1) belongs to a family of cysteine-rich, glycosylated signaling proteins that mediate diverse developmental processes, such as control of cell proliferation, adhesion, polarity and fate. WNT1-inducible signaling pathway protein 1 (WISP1) is induced by WNT1 and belongs to the CCN family, which includes CTGF (connective tissue growth factor), Cyr61 (cysteine-rich 61) and Nov (nephroblastoma-overexpressed gene). ${ }^{34}$ WISP1 is a target of the Wnt- $\beta$-catenin pathway, with its expression being regulated by $\beta$-catenin. ${ }^{35,36}$ WISP1 activity and availability are modulated by its interaction with decorin and biglycan, two extracellular matrixassociated proteoglycans that are abundant in bone and cartilage. ${ }^{37}$ The $2364 \mathrm{~A} \rightarrow \mathrm{G}$ polymorphism was shown to be related to spinal osteoarthritis in postmenopausal Japanese women, with the $G$ allele protecting against this condition. ${ }^{15}$ The $2364 \mathrm{~A} \rightarrow \mathrm{G}$ polymorphism (rs2929970) is located in the $3^{\prime}$-untranslated region of WISP1. An LD block containing this polymorphism includes $\sim 5.5 \mathrm{~kb}$ from intron 3 to $3^{\prime}$ region of the gene. We have now shown that this polymorphism was related to both the prevalence of hypertension and systolic and diastolic BP in Japanese men, with the variant $G$ allele representing a risk factor for hypertension, although the underlying mechanism of the association remains to be elucidated.

Our study has several limitations. (i) Given the multiple comparisons of genotypes with $\mathrm{BP}$ or the prevalence of hypertension in this study, it is not possible to exclude completely potential statistical errors such as false positives. (ii) It is possible that one or more of the polymorphisms related to BP or the prevalence of hypertension in our study are in LD with other polymorphisms of the same or nearby genes that are actually responsible for the development of hypertension. (iii) The functional relevance of the identified polymorphisms to gene transcription or to protein structure or function was not determined in this study. (iv) Given the lack of replication, validation of our findings will require their replication with independent subject panels.

In conclusion, our results suggest that the $682 \mathrm{~A} \rightarrow \mathrm{G}$ (Thr228Ala) polymorphism of SORBS1 and the $-30 \mathrm{G} \rightarrow$ A polymorphism of GCK may play a role in the development of hypertension in Japanese women and that the $2364 \mathrm{~A} \rightarrow \mathrm{G}$ polymorphism of WISP1 may play such a role in Japanese men. Determination of genotypes for these polymorphisms may prove informative for the assessment of the genetic risk for hypertension. Given that multiple variants, each having a small effect, will likely ultimately be found to be responsible for a large fraction of the genetic component of essential hypertension, identification of additional hypertension susceptibility genes will allow a more accurate assessment of the genetic risk for this condition.

\section{ACKNOWLEDGEMENTS}

This study was supported in part by Research Grants for Longevity Sciences (18C-02) from the Ministry of Health, Labor, and Welfare of Japan (to YY, FA and HS).

\section{CONFLICT OF INTEREST}

The authors declare no conflict of interest.

1 Lifton RP, Gharavi AG, Geller DS. Molecular mechanisms of human hypertension. Cell 2001; 104: 545-556.

2 Caulfield M, Munroe P, Pembroke J, Samani N, Dominiczak A, Brown M, Benjamin N, Webster J, Ratcliffe P, O'Shea S, Papp J, Taylor E, Dobson R, Knight J, Newhouse S, Hooper J, Lee W, Brain N, Clayton D, Lathrop GM, Farrall M, Connell J, MRC British Genetics of Hypertension Study. Genome-wide mapping of human loci for essential hypertension. Lancet 2003; 361: 2118-2123.

3 Gong M, Zhang H, Schulz H, Lee YA, Sun K, Bähring S, Luft FC, Nürnberg P, Reis A, Rohde K, Ganten D, Hui R, Hübner N. Genome-wide linkage reveals a locus for human essential (primary) hypertension on chromosome 12p. Hum Mol Genet 2003; 12: 1273-1277.

4 de Lange M, Spector TD, Andrew T. Genome-wide scan for blood pressure suggests linkage to chromosome 11 , and replication of loci on 16, 17, and 22. Hypertension 2004; 44: 872-877.

5 Wallace C, Xue MZ, Newhouse SJ, Marcano AC, Onipinla AK, Burke B, Gungadoo J, Dobson RJ, Brown M, Connell JM, Dominiczak A, Lathrop GM, Webster J, Farrall M, Mein C, Samani NJ, Caulfield MJ, Clayton DG, Munroe PB. Linkage analysis using co-phenotypes in the BRIGHT study reveals novel potential susceptibility loci for hypertension. Am J Hum Genet 2006; 79: 323-331.

6 Yatsu K, Mizuki N, Hirawa N, Oka A, Itoh N, Yamane T, Ogawa M, Shiwa T, Tabara Y, Ohno S, Soma M, Hata A, Nakao K, Ueshima H, Ogihara T, Tomoike H, Miki T, Kimura A, Mano S, Kulski JK, Umemura S, Inoko H. High-resolution mapping for essential hypertension using microsatellite markers. Hypertension 2007; 49: 446-452.

7 Kato N, Miyata T, Tabara Y, Katsuya T, Yanai K, Hanada H, Kamide K, Nakura J, Kohara K, Takeuchi F, Mano H, Yasunami M, Kimura A, Kita Y, Ueshima H, Nakayama T, Soma M, Hata A, Fujioka A, Kawano Y, Nakao K, Sekine A, Yoshida T, Nakamura Y, Saruta T, 
Ogihara T, Sugano S, Miki T, Tomoike H. High-density association study and nomination of susceptibility genes for hypertension in the Japanese National Project. Hum Mol Genet 2008; 17: 617-627.

8 Cusi D, Barlassina C, Azzani T, Casari G, Citterio L, Devoto M, Glorioso N, Lanzani C, Manunta P, Righetti M, Rivera R, Stella P, Troffa C, Zagato L, Bianchi G. Polymorphisms of $\alpha$-adducin and salt sensitivity in patients with essential hypertension. Lancet 1997; 349: 1353-1357.

9 Siffert W, Rosskopf D, Siffert G, Busch S, Moritz A, Erbel R, Sharma AM, Ritz E, Wichmann HE, Jakobs KH, Horsthemke B. Association of a human G-protein $\beta 3$ subunit variant with hypertension. Nat Genet 1998; 18: 45-48.

10 Izawa H, Yamada Y, Okada T, Tanaka M, Hirayama H, Yokota M. Prediction of genetic risk for hypertension. Hypertension 2003; 41: 1035-1040.

11 Yamada Y, Matsuo H, Segawa T, Watanabe S, Kato K, Hibino T, Yokoi K, Ichihara S, Metoki N, Yoshida H, Satoh K, Nozawa Y. Assessment of the genetic component of hypertension. Am J Hypertens 2006; 19: 1158-1165.

12 Kohara K, Tabara Y, Nakura J, Imai Y, Ohkubo T, Hata A, Soma M, Nakayama T, Umemura S, Hirawa N, Ueshima H, Kita Y, Ogihara T, Katsuya T, Takahashi N, Tokunaga K, Miki T. Identification of hypertension-susceptibility genes and pathways by a systemic multiple candidate gene approach: the millennium genome project for hypertension. Hypertens Res 2008; 31: 203-212.

13 Lin WH, Chiu KC, Chang HM, Lee KC, Tai TY, Chuang LM. Molecular scanning of the human sorbin and SH3-domain-containing-1 (SORBS1) gene: positive association of the T228A polymorphism with obesity and type 2 diabetes. Hum Mol Genet 2001; 10 . 1753-1760.

14 Stone LM, Kahn SE, Fujimoto WY, Deeb SS, Porte Jr D. A variation at position -30 of the beta-cell glucokinase gene promoter is associated with reduced beta-cell function in middle-aged Japanese-American men. Diabetes 1996; 45: 422-428.

15 Urano T, Narusawa K, Shiraki M, Usui T, Sasaki N, Hosoi T, Ouchi Y, Nakamura T, Inoue S. Association of a single nucleotide polymorphism in the WISP1 gene with spinal osteoarthritis in postmenopausal Japanese women. J Bone Miner Metab 2007; 25: 253-258.

16 Shimokata H, Ando F, Niino N. A new comprehensive study on aging-the National Institute for Longevity Sciences, Longitudinal Study of Aging (NILS-LSA). J Epidemiol 2000; 10: S1-S9.

17 Yamada Y, Ando F, Niino N, Shimokata H. Association of polymorphisms of androgen receptor and klotho genes with bone mineral density in Japanese women. $J$ Mol Med 2005; 83: 50-57.

18 Yamada $\mathrm{Y}$, Ando F, Shimokata H. Association of a microsomal triglyceride transfer protein gene polymorphism with blood pressure in Japanese women. Int J Mol Med 2006; 17: 83-88.

19 Yamada $\mathrm{Y}$, Ando F, Shimokata H. Association of gene polymorphisms with blood pressure and the prevalence of hypertension in community-dwelling Japanese individuals. Int J Mol Med 2007; 19: 675-683.

20 Perloff D, Grim C, Flack J, Frohlich ED, Hill M, McDonald M, Morgenstern BZ. Human blood pressure determination by sphygmomanometry. Circulation 1993; 88 2460-2470.

21 Hanley JA, Negassa A, Edwardes MD, Forrester JE. Statistical analysis of correlated data using generalized estimating equations: an orientation. Am J Epidemiol 2003; 157: 364-375.

22 Ten Have TR, Morabia A. Mixed effects models with bivariate and univariate association parameters for longitudinal bivariate binary response data. Biometrics 1999; 55 : 85-93.
23 Lalouel J-M, Rohrwasser A. Development of genetic hypotheses in essential hypertension. J Hum Genet 2001; 46: 299-306.

24 Lin WH, Huang CJ, Liu MW, Chang HM, Chen YJ, Tai TY, Chuang LM. Cloning, mapping, and characterization of the human sorbin and SH3 domain containing 1 (SORBS1) gene: a protein associated with c-Abl during insulin signaling in the hepatoma cell line Hep3B. Genomics 2001; 74: 12-20.

25 Ribon V, Herrera R, Kay BK, Saltiel AR. A role for CAP, a novel, multifunctional Src homology 3 domain-containing protein in formation of actin stress fibers and focal adhesions. J Biol Chem 1998; 273: 4073-4080.

26 Ribon V, Printen JA, Hoffman NG, Kay BK, Saltiel AR. A novel, multifunctional c-Cbl binding protein in insulin receptor signaling in 3T3-L1 adipocytes. Mol Cell Biol 1998; 18: 872-879.

27 Baumann CA, Ribon V, Kanzaki M, Thurmond DC, Mora S, Shigematsu S, Bickel PE, Pessin JE, Saltiel AR. CAP defines a second signalling pathway required for insulinstimulated glucose transport. Nature 2000; 407: 202-207.

28 Hagiwara N, Kitazono T, Kamouchi M, Kuroda J, Ago T, Hata J, Ninomiya T, Ooboshi H, Kumai Y, Yoshimura S, Tamaki K, Fujii K, Nagao T, Okada Y, Toyoda K, Nakane H, Sugimori H, Yamashita Y, Wakugawa Y, Kubo M, Tanizaki Y, Kiyohara Y, Ibayashi S, lida M, Fukuoka Stroke Registry; Hisayama Study. Polymorphism in the sorbin and SH3-domain-containing-1 (SORBS1) gene and the risk of brain infarction in the Japanese population: the Fukuoka Stroke Registry and the Hisayama study. Eur $J$ Neurol 2008; 15: 481-486.

29 Postic C, Shiota M, Niswender KD, Jetton TL, Chen Y, Moates JM, Shelton KD, Lindner $\mathrm{J}$, Cherrington AD, Magnuson MA. Dual roles for glucokinase in glucose homeostasis as determined by liver and pancreatic $\beta$ cell-specific gene knock-outs using Cre recombinase. J Biol Chem 1999; 274: 305-315.

30 Fajans SS, Bell GI, Polonsky KS. Molecular mechanisms and clinical pathophysiology of maturity-onset diabetes of the young. N Engl J Med 2001; 345: 971-980.

31 Yamada K, Yuan X, Ishiyama S, Ichikawa F, Koyama KI, Koyanagi A, Koyama W, Nonaka $\mathrm{K}$. Clinical characteristics of Japanese men with glucokinase gene beta-cell promoter variant. Diabetes Care 1997; 20: 1159-1161.

32 Marz W, Nauck M, Hoffmann MM, Nagel D, Boehm BO, Koenig W, Rothenbacher D, Winkelmann BR. G(-30)A polymorphism in the pancreatic promoter of the glucokinase gene associated with angiographic coronary artery disease and type 2 diabetes mellitus. Circulation 2004; 109: 2844-2849.

33 Chiang FT, Chiu KC, Tseng YZ, Lee KC, Chuang LM. Nucleotide(-258) G-to-A transition variant of the liver glucokinase gene is associated with essential hypertension. Am J Hypertens 1997; 10: 1049-1052.

34 Tanaka S, Sugimachi K, Saeki H, Kinoshita J, Ohga T, Shimada M, Maehara Y, Sugimachi K. A novel variant of WISP1 lacking a von Willebrand type $C$ module overexpressed in scirrhous gastric carcinoma. Oncogene 2001; 20: 5525-5532.

35 Pennica D, Swanson TA, Welsh JW, Roy MA, Lawrence DA, Lee J, Brush J, Taneyhill LA, Deuel B, Lew M, Watanabe C, Cohen RL, Melhem MF, Finley GG, Quirke P, Goddard AD, Hillan KJ, Gurney AL, Botstein D, Levine AJ. WISP genes are members of the connective tissue growth factor family that are up-regulated in wnt-1-transformed cells and aberrantly expressed in human colon tumors. Proc Natl Acad Sci USA 1998; 95: $14717-14722$

$36 \mathrm{Xu} \mathrm{L}$, Corcoran RB, Welsh JW, Pennica D, Levine AJ. WISP-1 is a Wnt-1- and beta-catenin-responsive oncogene. Genes Dev 2000; 14: 585-595.

37 Desnoyers L, Arnott D, Pennica D. WISP-1 binds to decorin and biglycan. J Biol Chem 2001; 276: 47599-47607. 